\title{
TRAUMAHEAD
}

\author{
Preservation strategy.
}

\section{BY JEREMY SZAL}

$\mathrm{I}$ $m$ crunching over the bodies of the fallen when I see him: the warrior with the head swollen with nanomemories.

My skin is raw and bleeding where my black CombatSkin has been shredded open by human gunfire. I can smell my sour wounds. My weapons harness chafes my neck and I can't stop shivering against the icy wind. Nothing burns like the cold. But self-pity must wait. I grit my teeth and trudge over to the fallen warrior. I press my eight-fingered hand to the nape of his bloodstained neck, where his shattered helmet has exposed his bulging nanomemories. The nanofibres in my skin tighten, red latticework standing stark as the warrior's neck peels from his body in luminescent cubes. His vibrating nanomemory cells float to my outstretched hand, disintegrating on contact and merging with my nanofibre matrix.

It's like having a bucket of ice-cold water drip down my spine as the memories spear into my head. We were told to store only the highlights. No unnecessary clutter, no memories that others might share. I watch years of this warrior's life play out in fragments: his first time seeing the sprawling cityscape we built on this frozen, tidally locked moon. Meeting his wife the night we gathered to watch the solar flare. The day he signed up to fight the human invaders, after they broke our peace treaty.

The birth of his daughter.

My throat is locked tight as I stand. My neck and shoulders prickle with sweat, scarred flesh expanding as the warrior's nanomemories are rewritten to my biometrics. Fusing with my body, my consciousness on a molecular level. But the only memories I possess of Asher, my daughter, are my own. Her head resting on my chest as a child, wanting to listen to her father's heartbeat. Her insistence on joining the armed forces when she became old enough. Wearing that stubborn, determined look that reminds me so much of myself at her age. But the memories are grey, distorted. They don't have the crystalline clarity of nanomemory infusion. They're inscribed in pencil, not ink.

I continue along the frozen battlefield in search of nanomemories, hoping I will find hers. Ash and snow melt on my shoulders and soak into my CombatSkin. Before long, I've scavenged the nanomemories of 50 of our slaughtered warriors. Childhood upbringings, deaths, loves, disappointments. Scientific and technological breakthroughs. Seeing friends and family blown to twitching

bundles of flesh by human artillery. Brave soldiers donning their CombatSkins and thermal helmets and departing for the battlefield, knowing they will never return home. My numb muscles feel like flayed meat, my spinal column stretching as my body processes the constant stream of narratives.

Some guessed the peace treaty between our race and the humans would not last. Our existence interrupted their colonization plans for this moon, after all. And if there's one thing we know about humans: they do not like to share. Our Jhulivaan civilization predates theirs by 15 millennia, but they have the numbers, the determination, the sheer brute force to destroy us. It's not enough to take our home; they want to drive us to extinction. Pretend that we never existed, that they are the only race in the Universe. Despite their small physical stature, stout limbs and excessive body hair, we're so similar in appearance that perhaps they took our existence as an insult.

Only, we were prepared for this. We've archived our memories, our histories, fragments of our civilization, in nanomemories to be retrieved upon death. But memories are based on emotion. AIs process data and raw statistics. Emotional states are unreadable to them. The only thing that can store conscious experiences is another conscious being.

I allowed the nanofibre matrix to be installed atop my spinal column. It houses these fragmented memories, laced with love, hatred, acceptance, rage, fear - and the events that led up to them. I rub the fuzz along my swollen neck, not quite believing that I'm becoming pregnant with the ghosts of an entire civilization.

But no matter how many piles of mutilated corpses I sift through, no matter how many lifetimes and personalities I transfer into me, I cannot find my daughter. I cannot find her memories of me and our brief 90 lunar cycles together before the war. My weariness vanishes, my chest heaving as I run from body to body, hoping I will find her so she can live on inside me. The sea of dead faces gazes up at me with eyes like bullet holes. But none is hers. The howling wind lashes at my maimed face. I want to sink to my knees and punch the ice until my hands are blocks of bloody, frozen flesh.

$\rightarrow$ NATURE.COM Follow Futures:

\section{y @NatureFutures}

$f$ go.nature.com/mtoodm
I swallow, look up. There's a human warship in orbit. They'll be here soon, and I've collected all the nanomemories I can easily store. My stealth-ship is waiting to smuggle me off-world to the remaining survivors, where we'll stash our pool of nanomemories in a place inaccessible to humans. Let the haughty bastards think they've destroyed all trace of us. And one day, maybe a spacefaring explorer will uncover our time capsule and share who we once were with the Universe.

I exhale slowly and take one final glance at the smoking remains of the cityscape before crunching away over the ice. My nape and shoulders have swollen to twice their normal size. But there's a gaping hole in there, like a wound. I think of my daughter's face, her laughter, her anger, her stubborn bravery and outbursts, and all the things that made her mine. I know that one day, when I die or become senile, the memories will fade to smoke in my hands. But until then, as long as I can hold her, she'll be with me.

I press my hand over my heart as I stumble away from my home, pretending it's hers.

Jeremy Szal writes about galactic nightmares, little traumas and broken heroes looking for hope in dark worlds from Sydney, Australia. Get in touch at jeremyszal.comor@jeremyszal 